\title{
IMPLEMENTASI PEMBELAJARAN TEMATIK OLEH GURU KELAS PADA SEKOLAH DASAR DI-KECAMATAN LEMBAH SEGAR KOTA SAWAHLUNTO
}

\author{
Doni Warman \\ Islamic Religion Studies Study Program postgraduate Program Of Islamic \\ Institute of Islamic State (IAIN) Batusangkar \\ e-mail: doniwarman82@google.com
}

\begin{abstract}
Noen
Abstract: This study aims to determine the way of planning, how to implement, how the assessment of thematic learning by classroom teachers in elementary school in the district. Fresh V alley. City of Sawablunto. Type of research that writer use is Etnografi research. Data collection techniques are done by triangulation, inductive data analysis and qualitative research results emphasize the meaning of the generalization. Informants in this study are primary informants and additional informants . Data collection techniques in research are observation, interview and documentation. The result of the implementation of thematic teaching by the classroom teacher at elementary school in sub-district of fresh valley of sawablunto city is at learning planning stage. The class teacher at SD in Kecamatan Lembah Segar Kota Sawablunto uses various ways but the same goal is by analyzing SKL, KD and Syllabus designing RPP using the thematic RPP model, and listing RPP themes and components. the implementation of Thematic learning by classroom teachers is done by classroom teachers using: tying some subjects with one theme, explaining the material with various learning methods, inviting students to be more active in learning, creating a more comfortable classroom atmosphere, delivering the material in a relaxed but assessment phase, all teachers use evaluation way for KI-1, KI-2, and KI-4 done day with assessment rubric. For the assessment of KI-3 the teacher performs the assessment by means of training per 1 lesson and for daily test is done on 1 sub theme. For the evaluation of spiritual and social attitudes using a range of $S B, B, C$ or $K$ values.
\end{abstract}

Keywords: Implementation, thematic learning, Teacher

\section{PENDAHULAN}

Pembelajaran tematik merupakan salah satu model dalam pembelajaran terpadu (integrated instruction) yang merupakan suatu sistem pembelajaran yang memungkinkan siswa, baik secara individual maupun kelompok, aktif menggali dan merumuskan konsep serta prinsip- prinsip keilmuan secara holistik, bermakna, dan autentik. Pembelajaran tematik berorentasi pada praktik pembelajaran yang sesuai dengan kebutuhan dan perkembangan siswa. (Rusman, 2012 :254).

Dalam kurikulum 2013 pembelajaran tematik integratif menggunakan pendekatan saintifik. Pembelajaran tematik integratif 
merupakan pendekatan pembelajaran yang mengintegrasikan berbagai kompetensi dari berbagai mata pelajaran ke dalam sebuah tema tertentu. Pendekatan saintifik ini, dimaksudkan untuk memberikan pemahaman kepada siswa dalam hal mengenal, kemudian memahami berbagai materi untuk mendapat informasi. Dengan adanya pembelajaran ini, diharapkan siswa dapat berpikir dengan menyeluruh tanpa terpisahpisah. Dalam pembelajaran tematik integratif mata pelajaran Ilmu Pengetahuan Alam (IPA) dan Ilmu Pengetahuan Sosial (IPS) tidak dihilangkan, tetapi menjadi objek pembelajaran dalam tematik integratif. Artinya, kedua bidang tidak menjadi mata pelajaran tersendiri, tetapi bergabung ke dalam mata pelajaran.

Pembelajaran tematik integratif merupakan pendekatan pembelajaran mengintegrasikan berbagai kompetensi dari berbagai mata pelajaran kedalam berbagi tema. Guru merupakan subjek dari implementasi pembelajaran tematik integrativ ini untuk itu guru atau pendidik harus menyiapkan berbagai hal dalam hal mengajar, di antaranya:

1. Guru harus membuat rencana pembelajaran, penguasaan materi, penerapan strategi.

2. Guru juga harus menyiapkan materi ajar yang berupa tema-tema, yang sebelumnya pada KTSP pelajaran tersusun bardasarkan mata pelajaran.

3. Guru harus menyiapkan cara penilaian secara terintegrasi karena banyaknya jenis penilaian yang harus diterapkan.

4. Guru harus bisa mengiplikasikan pembelajaran tematik secara utuh dan menyeluruh (Trianto, 2010: 144)
Berdasarkan observasi yang penulis lakukan pada seluruh SD yang ada di Kecamatan Lembah Segar Kota Sawahlunto Sebanyak 14 SD, 4 SD di antaranya sudah menerapkan kurikulum 2013 dengan pembelajaran tematik. (observasi, SD 12 Kubang Barat Kecamatan Lembah Segar). Sedangkan wawancara yang penulis lakukan dengan guru kelas 5 SD 12 diperoleh informasi penerapan pembelajaran tematik secara sempurna dalam pembelajaran di kelas agak mengalami kendala, karena guru meresa kesulitan untuk melakukan penilaian pada seluruh KI'. Pembalajaran tematik belum mantap dari segi pelaksanaannya karena guru belum sepenuhnya memahami hakekat pembelajaran tematikserta penilaian secara terintergrasi dalam kurikulum 2013. (Rosi Desvirika, dan A.N. Nasbandiah wawancara pribadi, di SD 12 Kubang Barat Kecamatan Lembah Segar, Senin 24Juli 2017). Dari wawancara tersebut tergambar bahwa Guru Kelas masih kesulitan untuk mengimplementasikan pembelajaran tematik di sekolah. Untuk itu penulis ingin menindaklanjuti "Implementasi pembelajaran tematik oleh guru kelas pada Sekolah Dasar Se-Kecamatan Lembah Kota Sawahlunto”.

\section{PEMBELAY ARANTEMATIK}

\section{Pengertian Pembelajaran Tematik}

Pembelajaran tematik berarti suatu kegiatan pembelajaran dengan mengintegrasikan materi beberapa mata pelajaran dalam satu tema/ topik pembahasan. Sutirjo dan Sri Istuti Mamik menyatakan bahwa pembelajaran tematik merupakan suatu usaha untuk mengintegrasikan pengetahuan, keterampilan, nilai atau sikap pembelajaran, 
serta pemikiran yang kreatif dengan menggunakan tema. (Majid, 2014: 60).

Berdasarkan uraian di atas, dapat disimpulkan bahwa pembelajaran tematik integratif adalah pendekatan pembelajaran yang mengintegrasikan beberapa kompetensi dari berbagai bidang studi menjadi satu tema tertentu, sehingga siswa dapat memperoleh pengalaman belajar yang bermakna dan pengetahuannya tidak dibatasi dalam disiplin ilmu tertentu.

\section{Karakteristik Pembelajaran Tematik}

Sebagai suatu proses, pembelajaran tematik memiliki karakteristik sebagai berikut,

\section{a. Pembelajaran Berpusat Pada Peserta Didik}

Pembelajaran tematik dikatakan sebagai pembelajaran yang berpusat pada peserta didik, karena pada dasarnya pembelajaran tematik merupakan suatu sistem pembelajaran yang memberikan keleluasan pada peserta didik baik secara individu maupun kelompok. Peserta didik dapat aktif mencari, menggali dan menemukan konsep serta prinsip-prinsip dari suatu pengetahuan yang harus dikuasainya sesuai dengan perkembangannya.

Menekankan pembentukan pemahaman dan kebermaknaan. Pembelajaran tematik mengkaji suatu fenomena dari berbagai macam aspek yang membentuk semacam jalinan antar skemata yang dimiliki peserta didik, sehingga akan berdampak pada kebermaknaan dari materi yang dipelajari peserta didik. Hasil yang nyata didapat dari segala konsep yang diperoleh dan keterkaitannya dengan konsep-konsep lain yang di pelajari dan mengakibatkan kegiatan belajar lebih bermakna. Hal ini diharapkan akan berakibat kepada kemampuan peserta didik untuk dapat menerapkan perolehan belajarnya pada pemecahan masalah-masalah yang nyata dalam kehidupannya.

\section{b. Belajar Melalui Pengalaman Langsung}

Pada pembelajaran tematik diprogramkan untuk melibatkan peserta didik secara lansung pada konsep dan prinsip yang dipelajari dan memungkinkan peserta didik belajar dengan melakukan kegiatan secara langsung. Sehingga peserta didik akan memahmi hasil belajarnya sesuai dengan fakta dan peristiwa yang mereka alami, bukan sekadar informasi dari guru. Pendidik lebih banyak bertindak sebagai fasilitator dan katalisator yang membimbing kearah tujuan yang ingin dicapai. Sedangkan peserta didik sebagai aktor pencari fakta dan informasi untuk mengembangkan pengetahuannya.

\section{c. Lebih Memperhatikan Proses Dari Hasil Semata.}

Pada pembelajaran tematik dikembangkan pendekatan discoveri inquiry (penemuan terbimbing) yang melibatkan peserta didik secara aktif dalam proses pembelajaran yaitu mulai dari perencanaan, pelaksanaan sampai proses evaluasi. Pembelajaran tematik dilaksanakan dengan melibatkan hasrat, minat, dan kemampuan peserta didik, sehingga dimungkinkan peserta didik termotivasi untuk belajar terus menerus.

\section{d. Sarat Dengan Muatan Keterkaitan.}

Pembelajaran tematik memusatkan perhatian pada pengamatan dan pengkajian suatu gejala atau peristiwa dari beberapa 
mata pelajaran sekaligus, tidak memisahkan pada objek tertentu saja, Sehingga dimungkinkan peserta didik untuk memahami suatu fenomena pembelajaran dari segala sisi.

\section{Prinsip Pembelajaran Tematik}

Pembelajaran tematik (integrated thematic instruction, ITI) asalnya dikonseptualisasikan tahun 1970 an. Pendekatan pembelajaran ini awalnya dikembangkan untuk anak-anak berbakat dan bertalenta (gifted and talented), cerdas, pada program perluasan belajar, dan yang belajar cepat (Trianto, 2010: 64). Beberapa prinsip yang berkenaan dengan pembelajaran tematik integratif sebagai berikut:

a. Pembelajaran tematik integratif memiliki satu tema yang aktual dekat dengan dunia siswa dan ada dalam kehidupan seharihari. Tema ini menjadi satu pemersatu materi yang beragam dari beberapa mata pelajaran.

b. Pembelajaran tematik integratif perlu memilih materi beberapa mata pelajaran yang mungkin saling terkait. Dengan demikian materi-materi yang di pilih dapat mengungkapkan tema secara bermakna. Mungkin terjadi pengayaan horizontal dalam bentuk contoh aplikasi yang tidak termuat dalam standart isi. Namun ingat, penyajian materi pengayaan seperti ini perlu di batasi dengan mengacu pada tujuan pembelajaran.

c. Pembelajaran tematik integratif tidak boleh bertentangan dengan tujuan kurikulum yang berlaku tetapi sebaliknya pembelajaran tematik integratif harus mendukung pencapaian tujuan utuh kegiatan penbelajaran yang termuat dalam kurikulum.

d. Materi pembelajaran yang dapat di padukan dalam satu tema selalu mempertimbangkan karakteristik siswa seperti minat, kemampuan, kebutuhan, dan pengetahuan awal.

\section{Implementasi Pembelajaran Tematik di Sekolah Dasar}

Apabila pembelajaran tematik ini diimplementasikan di sekolah, akan ada beberapa implikasi bagi guru, sarana dan prasarana, dan pengaturan ruangan.

a. Guru akan dituntut untuk lebih kreatif dalam menyiapkan materi pembelajaran, memilih kompetensi dari berbagai pelajaran, serta mengemas dan menyuguhkan mata pelajaran jadi menarik, menyenangkan dan membuat siswa gembira

b. Siswa mesti mengikuti proses pembelajaran yang bisa memungkinkan bekerja secara individu atau kelompok atau bahkan cara-cara klasik. Semua itu tergantung pada sejauh mana kemampuan guru untuk mencari pilihan yang terbaik bagi siswa dalam mencari metode pembelajaran. Yang terpenting bagi siswa bisa mengikuti pembelajaran secara variatif.

c. Pelajaran tematik memerlukan sarana dan prasarana yang lebih kompleks. Pembelajaran ini kadang memerlukan desain khusus maupun sumber belajar yang ada di lingkungan yang siap di manfaatkan secara praktis. Pembelajaran ini memerlukan media pembelajaran bervariasi untuk memudahkan siswa 
dalam memahami konsep-konsep yang abstak.

Hal senada juga di ungkapkan oleh Asroha dan menambahkan tentang Pembelajaran tematik juga membutuhkan pengaturan ruangan. Pengaturan ruangan itu meliputi, penyesuaian pengukuran ruangan dengan tema yang disajikan, pengaturan bangku peserta didik yang sesuai dengan tema, kegiatan tak melulu di dalam ruangan, tetapi juga bisa dilakukan di luar ruangan.( (Asroha, 2014: 6)

\section{METODE PENEUTIAN}

Teknik pengumpulan data yang penulis lakukan dengan menggunakan triangulasi (gabungan), analisis data bersifat induktif dan hasil penelitian kualitatif lebih menekankan makna dari pada generalisasi hal ini sesuai dengan pendapat sugiono. Informan dalam penelitian ini terdiri atas informan utama dan informan tambahan. Instrumen dalam penelitian ini adalah peneliti sendiri dengan dibantu alat-alat seperti alat perekam suara, tape Recorder, kamera, alat tulis dan pedoman wawancara.

Teknik pengumpulan data yang penulis gunakan terdiri atas observasi yaitu pengamatan secara langsung keobjek penelitian untuk melihat dari dekat kegiatan yang dilakukan Wawancara mengemukakan bahwa wawancara digunakan sebagai teknik pengumpulan data apabila peneliti ingin melakukan studi pendahuluan untuk menemukan permasalahan yang harus diteliti dan apabila peneliti ingin mengetahui hal-hal dari responden yang lebih mendalam.

Teknik pengecekan keabsahan data digunakan dengan triangulasi berarti peneliti menggunakan teknik pengumpulan data yang berbeda-beda untuk mendapatkan data dari sumber yang sama. Peneliti menggunakan observasi partisipatif, wawancara mendalam, dan dukumentasi untuk sumber data yang sama secara serempak. Pengecekan keabsahan data (triangulasi) dari berbagai sumber dengan berbagai cara dan berbagai waktu.

Analisis data dilakukan dengan reduksi data yang berarti merangkum, memilih hal-hal yang pokok, memfokuskan pada hal-hal yang penting, dicari tema dan polanya membuang yang tidak perlu. Penyajian data dilakukan dalam bentuk uraian singkat, bagan, hubungan antar kategori, yang paling sering digunakan untuk menyajikan data dalam penelitian kualitatif adalah dalam teks yang bersifat naratif. Langkah ketiga dalam analisis data kualitatif menurut Miles dan Huberman adalah penarikan kesimpulan dan verifikasi. Kesimpulan awal yang dikemukakan masih bersifat sementara, dan akan berubah bila tidak ditemukan bukti-bukti yang kuat yang mendukung pada tahap pengumpulan data berikutnya ( Milles, 1994: 24)

\section{HASIL PENEUTIANDAN PEMBAHASAN}

Cara perencanaan pembelajaran tematik oleh guru kelas pada SD di Kec. Lembah Segar Kota Sawahlunto diperoleh keterangan dari guru kelas dalam perencanaan pembelajaran tematik adalah dengan menganalisi Standar Kompetensi Lulusan, Kompetensi Dasar, Dan Silabus yang akan melahirkan RPP yang digunakan guru sebagai pedoman dalam melaksanakan kegiatan pembelajaran di kelas seluruhnya telah menggunakan tema. Dalam penetapan tema, guru menggunakan 
tema-tema yang dekat dengan kehidupan siswa. (Rosi Desvirika, Dkk, wawancara guru kelas, Sabtu, 22 Juli 2017). Temuan ini mendukung pendapat Trianto bahwa penetapan tema dimulai dari lingkungan yang terdekat, dikenali oleh siswa dan ruang lingkupnya disesuaikan dengan usia dan perkembangan siswa, termasuk minat, kebutuhan, dan kemampuannya (Trianto 2011: 168).

Cara pelaksanaan pembelajaran tematik oleh guru kelas Pada SD di Kec. Lembah Segar Kota Sawahlunto diperoleh informasi dari hasil wawancara yang telah dilakukan dengan 4 orang kepala sekolah diperoleh keterangan kebetulan disini semua kelas sudah menerapkan kurikulum 2013 serta sekolah awal yang merupakan percontohan, selain di awal-awal itu saya melihat dilapangan seperti apa, pembelajaran diluar kelas seperti apa. Alhamdulilah mereka tidak ada kesulitan, memang di awal-awal bingung tapi setelah satu semester saya tanya saya ikuti alhamdulilah mereka, menurut info yang disampaikan kepada saya tidak masalah justru anak-anak itu semakin senang belajarnya. (Mardalis, wawancara dengan kepala sekolah, Sabtu 22 Juli 2017). Cara penilaian pembelajaran tematik oleh guru kelas di SD Kec. Lembah Segar Kota Sawahlunto dilakukan dengan beberapa tahap pertama untuk kompetensi inti-3 (pengetahuan) guru menggunakan teknik penilaian berupa tes tulis dilaksanakan setiap selesai menyampaikan satu sub tema dengan ulangan harian, selain itu ada juga ujian tengah semester (UTS) yang dilaksanakan setelah satu tema selesai dipelajari. Berdasarkan data observasi diperoleh informasi bahwa melakukan evaluasi pada aspek kognitif dirancang pada Pembelajaran
6 dalam tema dan yang terpenting dalam kurikulum 2013 untuk tematik adalah penilaian. Untuk aspek keterampilan guru kelas menggunakan teknik penilaian berupa penilaian kinerja. Penilaian kinerja ini dilaksanakan dengan cara meminta siswa untuk melakukan sebuah tugas pada situasi sesungguhnya dengan menerapkan pengetahuan dan keterampilan. Dari data observasi guru kelas melaksanakan penilaian kinerja pada saat siswa diminta secara berpasangan ke depan kelas dan bertukar hasil kerjanya berupa denah perjalanan dari rumah menuju sekolah, siswa membacakan denah milik teman lengkap dengan arah mata angin dan daerah yang dilaluinya secara bergantian diri (Hasil observasi, pada hari selasa, 26 Juli 2017).

Perencanaan pembelajaran tematik dilakukan oleh guru dengan cara menganalisi Standar Kompetensi Lulusan, Kompetensi Dasar, dan Silabus dan nantikan akan muncul RPP yang digunakan guru sebagai pedoman dalam melaksanakan kegiatan pembelajaran di kelas seluruhnya telah menggunakan tema. Dalam penetapan tema, guru menggunakan tema-tema yang dekat dengan kehidupan siswa. Temuan ini mendukung pendapat Trianto bahwa penetapan tema dimulai dari lingkungan yang terdekat, dikenali oleh siswa dan ruang lingkupnya disesuaikan dengan usia dan perkembangan siswa, termasuk minat, kebutuhan, dan kemampuannya (Trianto 2010: 168)

Menurut Prabowo komponen dalam identitas mata pelajaran berisi nama mata pelajaran yang akan dipadukan, kelas, semester dan waktu/banyaknya jam pertemuan yang dialokasikan (Trianto, 2010: 169). Pada RPP yang digunakan oleh guru 
kelas pada SD di Kecamatan Lembah Segar Kota Sawahlunto dengan mencantumkan nama mata pelajaran dalam identitas mata pelajaran, identitas kelas dan semester pada identitas mata pelajaran, serta alokasi waktu yang jelas. RPP di mencantumkan KI dan KD pada setiap mata pelajaran yang akan digabungkan indikatornya. Tujuan pembelajaran yang baik, seluruh guru kelas menggunakan format audience, behaviour, condition, dan degree (ABCD) secara penuh. dan ini didukung dengan RPP yang dipakai oleh guru menggunakan format tersebut. Seluruh materi pokok telah dituliskan dalam RPP.

Letak penulisan materi pokok seragam, tidak ada lagi yang dituliskan sebelum kegiatan pembelajaran, atau yang dituliskan setelah langkah-langkah kegiatan pembelajaran. Alat dan media dalam RPP tematik ini sudah disebutkan akan menggunakan apa-apa saja. Alat dan media tersebut digunakan untuk memperlancar pencapaian kompetensi dasar, serta sumber bahan yang digunakan dalam kegiatan pembelajaran tematik sesuai dengan kompetensi dasar yang harus dikuasai.

Pembelajaran terpadu menekankan pada praktik pembelajaran yang sesuai dengan kebutuhan dan perkembangan siswa. Pendekatan ini berawal dari teori pembelajaran yang menolak proses hafalan/latihan. Pengajaran tematik adalah tentang bagaimana siswa secara aktif membangun pengetahuannya sendiri. Salah satu model dalam pembelajaran terpadu yang merupakan suatu sistem pembelajaran yang memungkinkan siswa secara individual maupun kelompok, aktif menggali dan menemukan konsep serta prinsip-prinsip keilmuan secara menyeluruh, bermakna dan autentik adalah pembelajaran tematik (Rusman, 2012: 254). Seluruh kegiatan pembelajaran yang dituliskan dalam RPP yang menggunakan strategi untuk mengajak siswa aktif, seperti diskusi, tanya jawab dan demonstrasi.

Dalam pelaksanaan pembelajaran tematik, guru harus membuat kegiatan yang di dalamnya memberikan kesempatan pada siswa untuk berperan aktif dalam seluruh kegiatan. Seluruh kegiatan pembelajaran yang berlangsung di dalam kelas memberikan kesempatan bagi siswa untuk menjawab pertanyaan, baik itu pertanyaan yang ditanyakan oleh guru maupun pertanyaan yang ditanyakan oleh teman satu kelas. Seluruh kegiatan pembelajaran juga memberikan kesempatan kepada siswa untuk mengajukan pertanyaan-pertanyaan yang berhubungan dengan materi yang dipelajarinya.

Metode diskusi adalah sebuah desain yang memberikan kesempatan untuk diadakannya pertukaran pikiran antara guru dengan siswa serta siswa dengan siswa. Dengan kata lain, siswa yang dalam kegiatan pembelajarannya menggunakan metode diskusi tidak bisa hanya menjadi pendengar pasif dan guru tidak akan menjadi pemain tunggal yang mendominasi kegiatan di dalam kelas.

Dalam kegiatan pembelajaran di kelas, guru sudah menerapkan metode diskusi kelompok untuk menyelesaikan suatu pertanyaan atau permasalahan. Guru mengalami sudah bisa menentukan pembagian kelompok, apakah dikelompokkan berdasarkan tingkat kepandaiannya, yang pandai dengan yang pandai, dan yang kurang pandai dengan yang kurang pandai, atau dibagi rata tingkat kepandaiannya. Dalam melaksanakan 
pembelajaran tematik di sekolah dasar, guru perlu menguasai berbagai macam kegiatan yang menarik. Siswa diberi kesempatan untuk menanyakan hal-hal yang berhubungan dengan materi yang kurang dipahami.

Melalui pertanyaan-pertanyaan yang diajukan guru, siswa diarahkan untuk menemukan konsep yang sedang dipelajarinya. Dalam menemukan konsep, siswa juga dibimbing oleh guru agar tidak salah memahami konsep yang dipelajarinya. Saat guru menyampaikan materi pokok, guru menghubungkan materi tersebut dengan kehidupan sehari-hari siswa melalui pertanyaan-pertanyaan yang diajukan guru. Dengan dihubungkannya materi dengan kehidupan yang dekat dengan siswa, maka siswa akan lebih mudah untuk memahami materi tersebut.

Dalam kegiatan pembelajaran di dalam kelas, guru sebagian besar menyediakan alat peraga yang memudahkan siswa untuk memahami materi yang dipelajarinya. Temuan tersebut sangat sesuai dengan prinsip pembelajaran tematik sebagaimana dikatakan oleh Rusman dalam kegiatan pembelajaran tematik perlu mengoptimalisasi penggunaan media pembelajaran yang bervariasi sehingga kegiatan pembelajaran akan berlangsung secara efektif (Rusman, 2012: 274).

Materi disampaikan secara berurutan, tidak serta merta berpindah, tidak melompat-lompat dari mata pelajaran satu ke mata pelajaran lain atau kembali lagi ke mata pelajaran sebelumnya. Dengan penyampaian yang sistematis ini, maka siswa tidak akan mengalami kebingungan dalam memahami konsep dari berbagai mata pelajaran.
Melalui kegiatan tanya jawab antara guru dan siswa, materi pada setiap mata pelajaran dihubungkan dengan pengalaman yang didapat mereka dalam kehidupan sehari-hari. Dengan cara seperti ini siswa akan lebih mudah memahami apa yang dipelajarinya. Anak-anak mengonstruksi pengetahuan mereka berdasarkan pengalaman. Anak-anak tidak hanya mengumpulkan hal-hal yang telah mereka pelajari, mereka menggabungkan pengalamanpengalamannya untuk memahami segala sesuatu yang berada di dunia. Ada kegiatan pembelajaran yang disesuaikan dengan kondisi kelas, adapula kegiatan pembelajaran yang antara RPP dengan kegiatanpembelajaran di kelas berbeda, sehingga tidak dapat dinilai sesuai atau tidak.

Penilaian dalam pembelajaran tematik adalah suatu usaha untuk mendapatkan berbagai informasi secara berkala, berkesinambungan, dan menyeluruh tentang proses dan produk dari pertumbuhan dan perkembangan yang telah dicapai peserta didik melalui kegiatan belajar (Permendikdub, N0 67: 2013)

Objek dalam penilaian pembelajaran tematik mencakup penilaian terhadap proses dan hasil belajar siswa. Penilaian proses belajar adalah upaya pemberian nilai terhadap kegiatan pembelajaran yang dilakukan oleh guru dan peserta didik. Penilaian proses meliputi Sikap Spritual, soaial dan ktrampilan. Dan untuk penilaian KI 3 (Kognitif) atau hasil belajar adalah proses pemberian nilai terhadap hasil-hasil belajar yang dicapai oleh peserta didik, dengan menggunakan kriteria- kriteria tertentu (Trianto, 2010: 260).

Berdasarkan hasil pengamatan dan 
observasi yang peneliti lakukan di pada informan sebanyak 3 kali, seluruh guru yang melakukan evaluasi Untuk KI 1 dilakukan Setiap hari, KI 2 Juga setiap Hari serta KI 4 setiap hari dengan rubrik penilaian yang disediakan sekolah berdasarkan pada permendibud Tentang Penilaian Hasil Belajar Oleh Pendidik Pada Pendidikan Dasar dan Menengah. Untuk penilaian KI 3 guru Melakukan penilaian dengan cara latihan per 1 kali pembelajaran dan untuk Ulangan hariannya dilakukan pada per 1 sub tema (Permendikbud, No 14: 2014)

Diakhir kegiatan pembelajaran, guru melakukan kegiatan evaluasi. Evaluasi yang selalu dilaksanakan oleh guru adalah evaluasi hasil belajar dalam bentuk tes tertulis. Hal ini sesuai dengan prinsip evaluasi pembelajaran terpadu dari uraian di atas dapat penulis simpulkan bahwa guru perlu mengajak para siswa untuk mengevaluasi perolehan belajar yang telah dicapai berdasarkan kriteria keberhasilan pencapaian tujuan yang akan dicapai. Prinsip penilaian yang menyeluruh salah satunya yaitu semua aspek peserta didik dinilai, baik kognitif, afektif, maupun psikomotor.

\section{PENUTP}

\section{Kesimpulan}

Dari pembahasan di atas dapat disimpulkan implementasi pembelajaran temamatik oleh guru kelas di Kecamatan Lembah Segar Kota Sawahlunto diimplementasikan melalui tiga tahap. Pada tahap perencanaan guru kelas menganalisis $\mathrm{KI}$ dan $\mathrm{KD}$ serta tujuan pembelajaran sehingga munculah RPP yang akan digunakan untuk proses pembelajaran. Pada tahap pelaksanaan guru kelas mengintegrasikan semua mata pelajaran dalam bentuk tematik dan menggunakan metode yang bervariasi untuk menciptakan prose belajar yang kondusif. Pada tahap penilaian guru kelas melaksanakan penilaian melalui tiga aspek yaitu kognitif, sikap religius, sikap sosial, dan keterampilan.

\section{Saran}

Berkaitan dengan penelitian yang lakukan, disarankan kepada pemerintah khususnya Kementrian Pendidikan dan Kebudayaan untuk mematangkan pelaksanaan Kurikulum 2013, terutama dalam hal penyiapan dan distribusi buku maupun pedoman teknis penilaian pem- belajaran. untuk menyiapkan fasilitas guna mendukung pelaksanaan Kurikulum 2013. Saran kepada guru adalah memanfaatkan forum pertemuan antar guru untuk saling belajar tentang kurikulum 2013.

\section{KEPUSTAKAANACUAN}

Kemendikbud, 2013, Permendikbud No 67 Tabun 2013 tentang Kerangka Dasar dan Struktur Kurikulum Sekolah Dasar/Madrasab Ibtidaiyah, Jakarta: Kemendikbud

Lampiran Peraturan Mentri Pendidikan dan Kebudayaan Republik IndonesiaNomor 66 Tahun 2013 Tentang Standar Penilaian Pendidikan.

Majid, Abdul, 2014, Pembelajaran Tematik Terpadu. Bandung: Remaja Rosda karya

Milles, Mattew B \& Huberman, A Michael. 1994. Qualitative Data Analysis. California: SAGE Publications. Inc

Peraturan menteri pendidikan dan 
kebudayaan Republik Indonesia Nomor 104 tahun 2014 Tentang Penilaian hasil belajar oleh pendidik Pada pendidikan dasar dan pendidikan menengah.

Rusman, 2012, Model-Model Pembelajaran : Mengembangkan Profesional Guru, Jakarta: Rajawali Press.
Riduwan, 2005, Belajar Mudah Penelitian Untuk Guru, Karyawan Dan Peneliti Pemula. Bandung: Alfabeta

Sugiono, 2008, Memahami Penelitian Kualitatif, Bandung: Alfabeta.

Trianto. 2010, Model Pembelajaran terpadu Konsep Strategi dan implentasinya Dalam KTSP, Jakarta: Bumi Aksara 